\title{
Editorial
}

Respiralion

\section{Dyspnea: The Importance of a Psychological Approach}

\author{
Roberto Duranti \\ Section of Clinical Immunology, Allergology and Respiratory Diseases, Department of Internal Medicine, \\ University of Florence, Florence, Italy
}

According to the statement of the American Thoracic Society [1], dyspnea is defined as 'a subjective experience of breathing discomfort that consists of qualitatively distinct sensations that vary in intensity. The experience derives from interactions among multiple physiological, psychological, social, and environmental factors'. Physiological studies have clarified what are the main mechanisms contributing to the generation of dyspnea: a central role is developed by respiratory muscle effort, which reflects central motor command; an important contribution is also given by the instantaneous feedback from mechanical receptors for volume, flow, muscle tension and shortening and chest wall displacement; afferent information from chemoreceptors also influences the development of dyspnea sensation [2-6]. Differently from physiological mechanisms, neuropsychological factors involved in the perception of dyspnea sensation have been less investigated [7]. In particular, the following areas need to be extensively investigated: the cortical structures involved in the perception of dyspnea, the role of peripheral afferents in the control of dyspnea sensation and the psychological aspects of dyspnea sensation. An important contribution to the understanding of the mechanism of dyspnea can be given by comparing pain and dyspnea [8]. These two different sensations share many characteristics and possibly several mechanisms. Like dyspnea, pain is a multidimensional sensory experi-

\section{KARGER}

Fax +4161306 1234

E-Mail karger@karger.ch

www.karger.com
(C) 2006 S. Karger AG, Basel

0025-7931/06/0736-0739\$23.50/0

Accessible online at:

www.karger.com/res ence associated with a strong cognitive and emotional component [9]. It is an unpleasant sensation associated with dangerous stimuli and it is strong enough to obtain immediate attention with the aim of preventing damage to tissue [9]. Thus, pain and dyspnea carry on a fundamental function of protection for the individual by informing him about the occurrence of damage. However, the chronic presence of pain or dyspnea becomes a relevant clinical problem, and their control constitutes an important task for the physician. In this sense understanding the mechanisms that control both pain and dyspnea may be very useful for establishing an efficacious therapy. However, the understanding of the mechanisms that control pain sensation is much more advanced compared to that of dyspnea. On one side, the observation that stimulation of large afferents inhibits the spinal transmission of nociceptive messages [10] opened the way to new methods of pain treatment based on selective afferent stimulation [11]. On the other side, the observation of the difference between sensory and affective components of pain led to the development of new intervention techniques [12]. In the last years, a similar approach is developing also for dyspnea. In 1991, Wilson and Jones [13] showed that it is possible to distinguish at least two dimensions in the perceived breathlessness: the sensory (i.e. intensity) and the distressing (i.e. affective) one. These two components showed a different behavior: 
mean intensity was greater than mean distress and the slope intensity/ventilation was higher than the slope distress/ventilation. This is an important point, because, as shown by Wilson and Jones [13], a breathlessness of high intensity is not necessarily associated with a high distress. The affective dimension is probably more disturbing for the subjects than the physical dimension, similarly to what is observed for pain sensation: visceral pain which is associated with a great affective component is much more badly tolerated than somatic pain. Successive studies devoted to investigate the psychological aspects of dyspnea demonstrated the validity of measurements of breathing distress [14-16]. More recently, Carrieri-Kohlmann et al. [17] demonstrated that exercise training induces a reduction in both intensity of dyspnea and the associated distress and anxiety, independently from any change in ventilation, suggesting that the improvement of dyspnea with rehabilitation programs is due in part to a desensitization effect. The paper by von Leupoldt et al. [18], published in this issue of Respiration, investigates the different influence of sensory and affective aspects on the global intensity of dyspnea. These authors have shown that the global dyspnea rating obtained using the Borg score is influenced by the sensory component (intensity) when the subject is concentrated on breathing and by the affective component when the subject is distracted from his breathing. This is an important observation because it demonstrates that it is possible to influence the different dimensions of dyspnea separately. On this basis future studies should investigate the relieving effects of cognitive techniques and the possibility to influence the affective component of dyspnea. This study also indicates the utility of measuring not only the intensity of dyspnea but also the magnitude of the associated distress in studies devoted to investigate the mechanisms of dyspnea control.

\section{References}

1 Dyspnea: mechanisms, assessment, and management: a consensus statement. American Thoracic Society. Am J Respir Crit Care Med 1999;159:321-340.

2 Killian KJ, Campbell JM: Dyspnea; in: Roussos C (ed): The Thorax, Part B: Applied Physiology. New York, Dekker, 1995, pp 1709-1747.

3 Manning HL, Schwartzstein R: Pathophysiology of dyspnea. N Engl J Med 1995;23: 1547-1553.

4 O'Donnel DE: Breathlessness in patients with chronic airflow limitation. Chest 1994; 106:904-912.

5 Chronos N, Adams L, Guz A: Effect of hyperoxia and hypoxia on exercise-induced breathlessness in normal subjects. Clin Sci 1988;74:531-537.

6 Banzett RB, Lansing RW, Reid MB, Adams L, Brown R: 'Air hunger' arising from increased $\mathrm{PCO}_{2}$ in mechanically ventilated quadriplegics. Respir Physiol 1989;76:5367.

7 von Leupoldt A, Dahme B: Cortical substrates for the perception of dyspnea. Chest 2005; 128:345-354.
8 Banzett RB, Moosavi SH: Dyspnea and pain: similarities and contrasts between two very unpleasant sensations. APS Bull 2001;11: $1-8$.

9 Wolff CJ: Pain: moving from symptom control toward mechanism-specific pharmacologic treatment. Ann Intern Med 2004;140: 441-451.

10 Melzack R, Wall PD: Pain mechanisms: a new theory. Science 1965;150:971-979.

11 Carroll D, Moore RA, McQuay HJ, Fairman HJ, Tramèr M, Leijon G: Transcutaneous electrical nerve stimulation (TENS) for chronic pain. Cochrane Database of Systematic Reviews 2000, issue 4

12 Turk DC: Cognitive-behavioral approach to the treatment of chronic pain patients. Reg Anesth Pain Med 2003;28:573-579.

13 Wilson RC, Jones PW: Differentiation between the intensity of breathlessness and the distress it evokes in normal subjects during exercise. Clin Sci 1991;80:65-70.
14 Carrieri-Kohlman V, Gormley JM, Douglas MK, Paul SM, Stulbarg MS: Differentiation between dyspnea and its affective components. West J Nurs Res 1996;18:626-642.

15 Meek PM, Lareau SC, Hu J: Are self-reports of breathing effort and breathing distress stable and valid measures among persons with asthma, persons with COPD, and healthy persons? Heart Lung 2003;30:335346 .

16 von Leupoldt A, Dahme B: Differentiation between the sensory and affective dimension of dyspnea during resistive load breathing in normal subjects. Chest 2005;128:33453349.

17 Carrieri-Kohlman V, Gormley JM, Douglas MK, Paul SM, Stulbarg MS: Exercise training decreases dyspnea and the distress and anxiety associated with it. Monitoring alone may be as effective as coaching. Chest 1996; 110:1526-1535.

18 von Leupoldt A, Ambruzsova R, Nordmeyer S, Jeske N, Dahme B: Sensory and affective aspects of dyspnea contribute differentially to the Borg scale's measurement of dyspnea. Respiration 2006;73:762-768. 